Article

\title{
An Efficient Method for the $N$-Bromosuccinimide Catalyzed Synthesis of Indolyl-Nitroalkanes
}

\section{Chun-Wei Kuo, Chun-Chao Wang, Hu-Lin Fang, B. Rama Raju, Veerababurao Kavala, Pateliya Mujjamil Habib and Ching-Fa Yao *}

Department of Chemistry, National Taiwan Normal University, 88, Sec. 4, Tingchow Road, Taipei 116, Taiwan

* Author to whom correspondence should be addressed; E-Mail: cheyaocf@ntnu.edu.tw; Tel.: +886-2-2930-9092; Fax: +886-2-2932-4249.

Received: 25 August 2009; in revised form: 25 September 2009 / Accepted: 27 September 2009 / Published: 9 October 2009

\begin{abstract}
An efficient and practical method for the synthesis of indolyl-nitroalkane derivatives catalyzed by $N$-bromosuccinimide is described. The generality of this method was demonstrated by synthesizing an array of diverse 3 -substituted indole derivatives by the reaction of different $\beta$-nitrostyrenes with various substituted indoles. Simple reaction conditions accompanied by good yields of indolyl-nitroalkanes are the merits of this methodology.
\end{abstract}

Keywords: indolyl-nitroalkane; $N$-bromosuccinimide; nitroalkenes; Friedel-Crafts alkylation

\section{Introduction}

The indole nucleus is one of the most ubiquitous scaffolds found in natural products, pharmaceuticals, functional materials, and agrochemicals [1-3]. Several indole derivatives that occur in nature possess pharmacological activity. These include the hapalindole alkaloids, which exhibit significant antibacterial and antimycotic activity. Other indole alkaloids are uleine, aspidospermidine, the ibophyllidine alkaloids, brevicolline and numerous tryptamine derivatives which exhibit important biological activities (Figure 1) [4-6]. 
Figure 1. Indole alkaloids.<smiles>C=C[C@]1(C)[C@H](Cl)C[C@@H]2[C@H](c3c[nH]c4cccc(c34)C2(C)C)[C@H]1C</smiles>

Hapalindole G

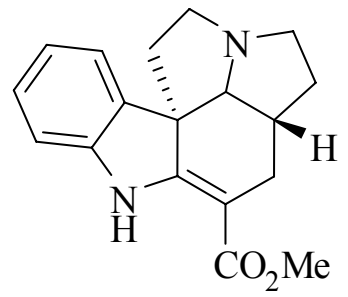

Deethylibophyllidine

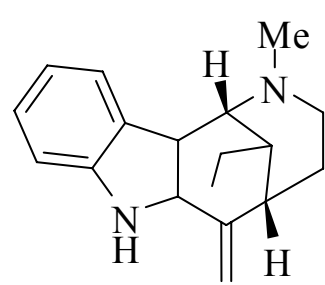

Uleine

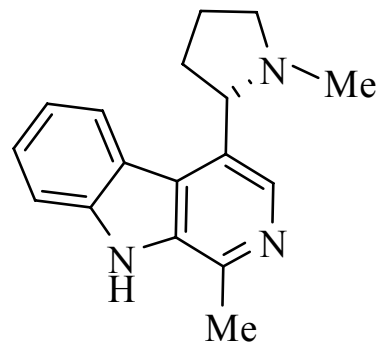

Brevicolline

Owing to the importance of the indole framework-containing compounds, the development of new strategies to synthesize indole derivatives remain a subject of interest in the present days. During the past several years, Michael addition was the most frequently employed tool for the synthesis of 3substituted indole derivatives [7]. This is due to the fact that nitroalkenes are very good Michael acceptors and further the Michael adduct of the nitroalkenes are amenable to transformation into a wide range of different functionalized species. Similarly, Friedel-Crafts alkylation of indoles with nitroolefins in the presence of acidic catalysts is well documented in the literature [8-22]. Neverthless, most of the procedures reported suffer from several shortcomings such as the use of hazardous catalysts, tedious workup procedures and difficulties in product isolation. The most important drawback is the tendency of electron-rich heteroaromatic rings to undergo polymerization under acid catalyzed conditions. Hence the development of an effective method for the synthesis of 3-substituted indoles has still remained a problem far from resolution. In addition, recent progress in the stereoselective synthesis of these compounds was reported [23,24].

$\mathrm{N}$-Bromosuccinimide (NBS), a mild source of bromine, is widely used in the presence of a catalytic amount of free-radical initiators for benzylic and allylic brominations with high regioselectivity [25]. In many instances, NBS have been used as an activator in stereoselective glycosidation [26], protection [27] and deprotection of ketals [28] or THP ethers [29] and in the synthesis of diindolylalkanes [30]. It is also widely employed as a mild oxidant [31] as well as for oxidative cyclizations [32,33]. Recently, we have reported synthesis of 1,5-benzodiazepine derivatives catalyzed by NBS under mild conditions [34]. In continuation of our research work on nitroolefins [35-43], we have developed a new route for the synthesis of 3-alkylated indoles via Friedel-Crafts alkylation of indole with $\beta$-nitrostyrene, catalyzed by $N$-bromosuccinimide.

\section{Results and Discussion}

Initially, we examined the reaction between $\beta$-nitrostyrene and indole with $10 \mathrm{~mol} \%$ of $N$-bromosuccinimide in dichloromethane at room temperature (Scheme 1). We were able to obtain only $67 \%$ of the corresponding alkylated adduct. Further, we examined the fate of the reaction at elevated temperatures. Conducting the reaction at $40{ }^{\circ} \mathrm{C}$ afforded the product in $94 \%$ yield, after $5 \mathrm{~h}$ (entry 3 , Table 1). With $20 \mathrm{~mol} \%$ of $N$-bromosuccinimide, the product yield remained the same, along with the same reaction time as when $10 \mathrm{~mol} \%$ of NBS was utilized. Our optimization studies showed that 
$10 \mathrm{~mol} \%$ of $\mathrm{N}$-bromosuccinimide could be the best choice for this transformation, which is evident from Table 1.

Scheme 1. Alkylation of indole with $\beta$-nitrostyrene.

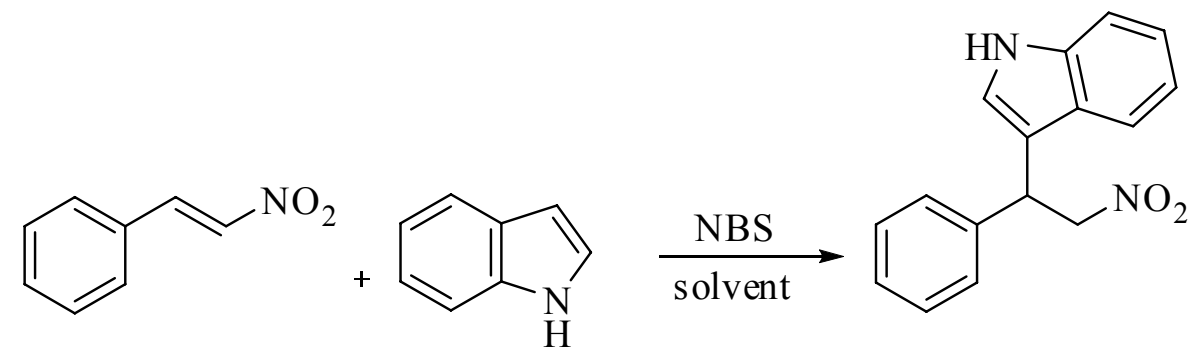

Table 1. Optimization studies of the alkylation reaction of indole and $\beta$-nitrostyrene.

\begin{tabular}{cccccc}
\hline Entry & NBS (mol \%) & Solvent & Condition & Time (h) & Yield (\%) \\
\hline 1 & 10 & $\mathrm{CHCl}_{3}$ & $\mathrm{rt}$ & 16 & 60 \\
2 & 10 & $\mathrm{CH}_{2} \mathrm{Cl}_{2}$ & $\mathrm{rt}$ & 12 & 67 \\
$\mathbf{3}$ & $\mathbf{1 0}$ & $\mathrm{CH}_{2} \mathrm{Cl}_{2}$ & $\mathbf{4 0}{ }^{\circ} \mathrm{C}$ & $\mathbf{5}$ & $\mathbf{9 4}$ \\
4 & 20 & $\mathrm{CH}_{2} \mathrm{Cl}_{2}$ & $40^{\circ} \mathrm{C}$ & 5 & 95 \\
5 & - & $\mathrm{CH}_{2} \mathrm{Cl}_{2}$ & $40^{\circ} \mathrm{C}$ & 5 & 13 \\
\hline
\end{tabular}

${ }^{a}$ Yields were determined from ${ }^{1} \mathrm{H}-\mathrm{NMR}$ with toluene as internal standard.

When $1 \mathrm{mmol}$ of $\beta$-nitrostyrene 1 was reacted with $1.3 \mathrm{mmol}$ of indole in the presence of $10 \mathrm{~mole} \%$ of $\mathrm{N}$-bromosuccinimide using dichloromethane as solvent at $40{ }^{\circ} \mathrm{C}$, the reaction afforded exclusively the corresponding indolyl-nitroalkane in good to excellent yields. To further explore the scope and limitations of this methodology, we tested the alkylation reaction of indole with a wide array of structurally diverse nitroalkenes (Scheme 2). As seen from Table 2, the alkylation of indoles proceeds with various nitroolefins. The rate of the reaction is controlled by both electronic and steric factors of the substituent attached to the benzene ring of the $\beta$-nitrostyrene. For example, the nitroolefins containing electron-withdrawing groups (chloro and nitro, entries 2 and 4, Table 2) react well to afford the 3-alkylated indoles in excellent yields. However, nitroalkenes equipped with strong electrondonating groups such as methyl or methoxy (entries 1 and 3) required relatively longer reaction times. Moreover, sterically hindered substrates (entries 5-8) reacted smoothly under the present reaction conditions. Acid sensitive heterocyclic moieties substrates such as thienyl (entry 9) and furoyl (entry 10) and less reactive aliphatic nitroalkenes (entries 11 and 12) also reacted with equal ease to furnish the Friedel-Crafts products in high yields. 1-Nitrocyclohex-1-ene (entry 13), upon reaction with indole resulted in a mixture of two diastereomers in 7:3 ratio. 
Scheme 2. Reaction of indole with various nitroalkenes catalyzed by NBS.

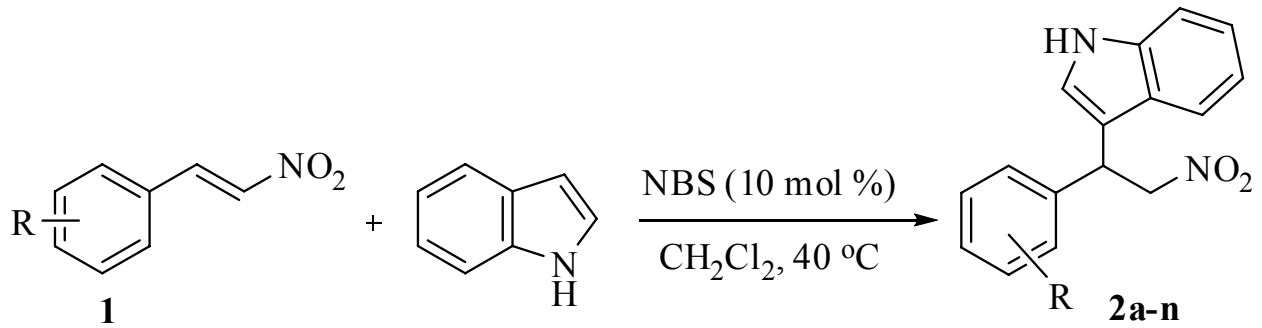

Table 2. Synthesis of indolyl-nitroalkane derivatives from various nitroalkenes.

\begin{tabular}{|c|c|c|c|c|c|}
\hline Entry ${ }^{a}$ & Nitroalkene & Product & & Time $(\mathrm{h})$ & Yield $(\%)^{b}$ \\
\hline 1 & & & $2 b$ & 10 & 89 \\
\hline 2 & & & $2 \mathrm{c}$ & 8 & 84 \\
\hline 3 & & & 2d & 16 & 87 \\
\hline 4 & & & $2 e$ & 4 & 85 \\
\hline 5 & & & $2 f$ & 18 & 90 \\
\hline 6 & & & $2 \mathrm{~g}$ & 24 & 87 \\
\hline 7 & $\mathrm{Br}$ & & $2 \mathrm{~h}$ & 6 & 85 \\
\hline 8 & & & $2 \mathbf{i}$ & 23 & 86 \\
\hline
\end{tabular}


Table 2. Cont.

Entry

${ }^{a}$ All reactions were performed by using 1 equiv. of nitroalkene and 1.3 equiv. of indole in the presence of $10 \mathrm{~mol} \%$ of NBS; $;^{\mathrm{b}}$ Isolated yields; ${ }^{\mathrm{c}} \mathrm{A}$ mixture of two diastereomers in 7:3 ratio.

Furthermore, to study the effect of the substituents on the heterocyclic substrate, the reaction of $\beta$ nitrostyrene with various substituted indole and other heterocyclic derivatives was examined (Scheme 3). 2-Methylindole was reacted with $\beta$-nitrostyrene to furnish the product $\mathbf{4 b}$ in high yield. Similarly, 5 -methoxyindole bearing an electron-donating group (entry 5, Table 3) was alkylated with $\beta$ nitrostyrene in a shorter time to give the desired product $\mathbf{4 e}$ in excellent yield. Moreover, increasing the size of the substituent on the indole nucleus, such as in the case of 2-phenylindole, gave only $47 \%$ yield. Generally, alkylation of hydroxyindoles with nitroalkenes often results in various side products, thereby decreasing the yields of alkylated product which may be due to the interaction of the hydroxyl group with the Lewis acid catalyst [44]. Indole containing free or protected hydroxyl group (entries 6, 8 and 9) reacted with the nitroolefin without any interference of the functional group. It is interesting to note that fused heteroarenes such as 7 -azaindole (entry 10, Table 3) reacted with $\beta$-nitrostyrene to afford the corresponding adduct in moderate yield after prolonged reaction time. This method was found to be quite successful with the highly nucleophilic substrate pyrrole (entry 11) and the acid sensitive substrate 2-methoxyfuran (entry 12), producing the expected products in better yields compared to the earlier reported methods [45]. 
Scheme 3. Reaction of $\beta$-nitrostyrene with various indoles and other heterocyclic compounds catalyzed by NBS.

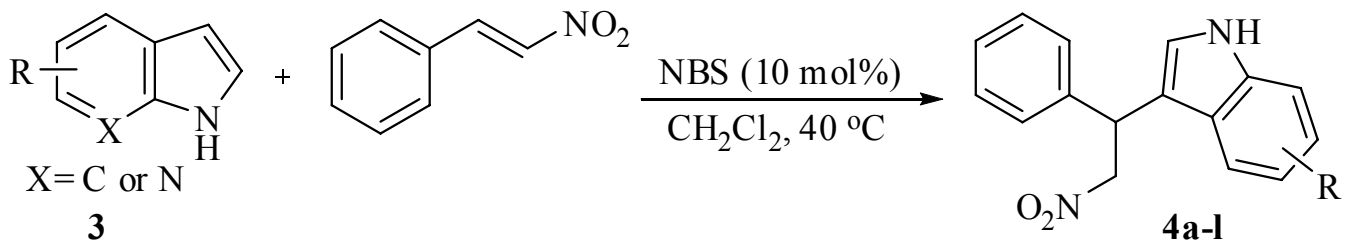

Table 3. Synthesis of aryl-nitroalkane derivatives from various indoles and other heterocyclic derivatives.

Entry


Table 3. Cont.

Entry ${ }^{\mathrm{a}}$

${ }^{\text {a }}$ All reactions were carried out by using 1 equiv. of nitroalkene and 1.3 equiv. of indole in the presence of $10 \mathrm{~mol} \%$ of NBS; ${ }^{b}$ isolated yields.

Scheme 4. Synthesis of the key precursor of $(S)$-brevicolline.<smiles>CC(C)(C)OC(=O)N1CCCC1/C=C/[N+](=O)[O-]</smiles>

An interesting application of this methodology involves the synthesis of the compound $\mathbf{6}$, which is the key precursor for the synthesis of the natural product $(S)$-brevicolline. The nitroalkene 5 was prepared by the condensation of Boc-S-pyrrolidine-2-carboxyaldehyde with nitromethane according to the reported procedure [46]. Compound 6 was obtained as a mixture of two diastereomers in the ratio of 9:1 (HPLC) in $80 \%$ yield by the reaction of indole with nitroalkene 5 under the present reaction conditions in $16 \mathrm{~h}$. The aforementioned example demonstrates the usefulness and versatility of this synthetic methodology.

\section{Conclusion}

In conclusion, we have developed a simple and efficient method for the synthesis of indolylnitroalkanes in good yields under catalytic conditions. This method is applicable to a wide range of nitroalkenes and various indoles. Low cost of the reagents and convenient isolation process of this reaction makes this method an attractive alternative to existing methods. 


\section{Experimental}

\section{General}

All reagents and chemicals were purchased from Sigma-Aldrich Chemical Company, Acros Organics, Alfa Aesar or Merck and were used as received. Analytical thin layer chromatography was performed with E. Merck silica gel $60 \mathrm{~F}$ glass plates and flash chromatography with E. Merck silica gel 60 (230-400 mesh). Melting points were determined with a microscope hot-stage apparatus and uncorrected. ${ }^{1} \mathrm{H}$ - and ${ }^{13} \mathrm{C}-\mathrm{NMR}$ spectra were recorded on a Bruker Avance 400 instrument. Chloroform- $d$ was used as the solvent and TMS $(\delta=0.00 \mathrm{ppm})$ as an internal standard. Chemical shift values are reported in ppm relative to TMS in delta $(\delta)$ units. Chemical shifts are recorded in parts per million (ppm). For ${ }^{1} \mathrm{H}-\mathrm{NMR}$ spectra the residual solvent peak was used as an internal reference $\left(\mathrm{CHCl}_{3}\right.$ 7.26). For ${ }^{13} \mathrm{C}$-NMR spectra the central peak of the $\mathrm{CDCl}_{3}$ triplet was used as the internal reference (77.26). Multiplicities are recorded as s, singlet; d, doublet; t, triplet; q, quartet; dd, doublet of doublet; br broadened; m, multiplet. Coupling constants $(\mathrm{J})$ are expressed in Hertz. MS and HRMS were measured on JEOL JMS-D300 and JEOL JMS-HX110 spectrometers, respectively.

\section{General procedure for the synthesis of aryl-nitroalkanes}

To a stirred solution of nitroalkene derivative $(1 \mathrm{mmol})$ and indole $(1.3 \mathrm{mmol})$ in $\mathrm{CH}_{2} \mathrm{Cl}_{2}(2 \mathrm{~mL})$ was added NBS $(0.1 \mathrm{mmol})$. The reaction mixture was then warmed to $40{ }^{\circ} \mathrm{C}$ with continuous stirring until the completion of the reaction as monitored by TLC. Upon completion, the reaction mixture was diluted with water and extracted with $\mathrm{CH}_{2} \mathrm{Cl}_{2}(3 \times 15 \mathrm{~mL})$, washed with brine, and then dried over $\mathrm{MgSO}_{4}$. The solvent was removed under reduced pressure and the crude residue was purified by flash chromatography on silica gel to afford pure product. The references of the known compounds are: $\mathbf{2 a}$ [14,15,17,19], 2b [36], 2c [15,22], 2d [13,15,17], 2e [36], 2f [36], 2g [22], 2j [15,22], 2k [15,36], cis2n [14], trans-2n [14], 4a [15,17,19], 4b [15,17], 4c [12,36], 4d [15], 4e [14,17], 4f [14], 4g [17,19], 4k [15,35], $4 \mathbf{l}[45], 5$ [46].

3-(1-(2-Bromophenyl)-2-nitroethyl)-1H-indole (2h): Colorless solid. mp 117-118 ${ }^{\circ} \mathrm{C} .{ }^{1} \mathrm{H}-\mathrm{NMR}$ $\left(400 \mathrm{MHz}, \mathrm{CDCl}_{3}\right): \delta 8.07$ (brs, $\left.1 \mathrm{H}\right), 7.61(\mathrm{~d}, J=7.8 \mathrm{~Hz}, 1 \mathrm{H}), 7.42(\mathrm{~d}, J=8.0 \mathrm{~Hz}, 1 \mathrm{H}), 7.33(\mathrm{~d}, J=8.2$ $\mathrm{Hz}, 1 \mathrm{H}), 7.20-7.18(\mathrm{~m}, 3 \mathrm{H}), 7.12-7.05(\mathrm{~m}, 3 \mathrm{H}), 5.72(\mathrm{t}, J=8.0 \mathrm{~Hz}, 2 \mathrm{H}), 4.99-4.90(\mathrm{~m}, 1 \mathrm{H}) ;{ }^{13} \mathrm{C}$ NMR $\left(100 \mathrm{MHz}, \mathrm{CDCl}_{3}\right): \delta 138.3(\mathrm{C}), 136.7(\mathrm{C}), 133.7(\mathrm{C}), 129.4(\mathrm{CH}), 129.3(\mathrm{CH}), 128.1(\mathrm{CH}), 126.4$ $(\mathrm{CH}), 124.7(\mathrm{CH}), 123.0(\mathrm{CH}), 122.1(\mathrm{C}), 120.2(\mathrm{CH}), 119.2(\mathrm{CH}), 113.6(\mathrm{C}), 111.6(\mathrm{CH}), 78.0\left(\mathrm{CH}_{2}\right)$, $40.8(\mathrm{CH})$; MS (EI) $\mathrm{m} / \mathrm{z}$ (relative intensity): $346(14)[\mathrm{M}+2]^{+}, 344(13)[\mathrm{M}]^{+}, 297$ (28), 218 (100), 204 (27), 108 (20); HRMS-EI: $m / z$ [M] $]^{+}$calcd. for $\mathrm{C}_{16} \mathrm{H}_{13} \mathrm{BrN}_{2} \mathrm{O}_{2}$ : 344.0160; found: 344.0155.

3-(2-Nitro-1-(2-nitrophenyl)ethyl)-1H-indole (2i): Yellow solid. mp 117-119 ${ }^{\circ} \mathrm{C} .{ }^{1} \mathrm{H}-\mathrm{NMR}(400 \mathrm{MHz}$, $\left.\mathrm{CDCl}_{3}\right): \delta 8.20(\mathrm{brs}, 1 \mathrm{H}), 7.89(\mathrm{~d}, J=7.8 \mathrm{~Hz}, 1 \mathrm{H}), 7.48-7.37(\mathrm{~m}, 3 \mathrm{H}), 7.32(\mathrm{dd}, J=12.7$ and $8.4 \mathrm{~Hz}$, 2H), $7.18(\mathrm{t}, J=7.6 \mathrm{~Hz}, 1 \mathrm{H}), 7.13(\mathrm{~s}, 1 \mathrm{H}), 7.03(\mathrm{t}, J=7.3 \mathrm{~Hz}, 1 \mathrm{H}), 5.87$ (t, $J=7.7 \mathrm{~Hz}, 1 \mathrm{H}), 5.09$ (m, 2H). ${ }^{13} \mathrm{C}-\mathrm{NMR}\left(100 \mathrm{MHz}, \mathrm{CDCl}_{3}\right): \delta 149.8(\mathrm{C}), 136.7(\mathrm{C}), 133.9(\mathrm{C}), 133.4(\mathrm{C}), 130.1(\mathrm{CH}), 128.8$ $(\mathrm{CH}), 126.1(\mathrm{CH}), 125.3(\mathrm{CH}), 123.2(\mathrm{CH}), 122.3(\mathrm{CH}), 120.4(\mathrm{CH}), 118.8(\mathrm{CH}), 113.0(\mathrm{C}), 111.7$ 
(CH), $78.3\left(\mathrm{CH}_{2}\right), 36.6(\mathrm{CH})$; MS (EI) m/z (relative intensity): 311 (19) [M] $]^{+}, 264$ (29), 247 (33), 219 (100), 204 (39), 130 (57); HRMS-EI: $m / z$ [M] calcd for $\mathrm{C}_{16} \mathrm{H}_{13} \mathrm{~N}_{3} \mathrm{O}_{4}$ : 311.0906 ; found: 311.0901.

3-(1-Nitromethylpentyl)-1H-indole (2I): ${ }^{1} \mathrm{H}-\mathrm{NMR}\left(400 \mathrm{MHz}, \mathrm{CDCl}_{3}\right): \delta 8.06$ (brs, $\left.1 \mathrm{H}\right), 7.61(\mathrm{~d}$, $J=7.8 \mathrm{~Hz}, 1 \mathrm{H}), 7.34(\mathrm{~d}, J=8.1 \mathrm{~Hz}, 1 \mathrm{H}), 7.23-7.18(\mathrm{~m}, 1 \mathrm{H}), 7.15-7.11(\mathrm{~m}, 1 \mathrm{H}), 6.98(\mathrm{~d}, J=2.0 \mathrm{~Hz}$, $1 \mathrm{H}), 4.59(\mathrm{~m}, 2 \mathrm{H}), 3.86(\mathrm{~m}, 1 \mathrm{H}), 1.89(\mathrm{~m}, 1 \mathrm{H}), 1.52(\mathrm{~m}, 2 \mathrm{H}), 0.89(\mathrm{~d}, J=6.0 \mathrm{~Hz}, 3 \mathrm{H}), 0.87(\mathrm{~d}$, $J=6.0 \mathrm{~Hz}, 3 \mathrm{H}) ;{ }^{13} \mathrm{C}-\mathrm{NMR}\left(100 \mathrm{MHz}, \mathrm{CDCl}_{3}\right): \delta 136.5(\mathrm{C}), 126.1(\mathrm{C}), 122.4(\mathrm{CH}), 122.1(\mathrm{CH}), 119.7$ $(\mathrm{CH}), 118.7(\mathrm{CH}), 114.1(\mathrm{C}), 111.5(\mathrm{CH}), 81.0\left(\mathrm{CH}_{2}\right), 41.4(\mathrm{CH}), 34.4\left(\mathrm{CH}_{2}\right), 25.4\left(\mathrm{CH}_{2}\right), 23.3\left(\mathrm{CH}_{2}\right)$, $21.5\left(\mathrm{CH}_{3}\right)$; MS (EI) m/z (relative intensity): 246 (19) $[\mathrm{M}]^{+}, 178$ (11), 157 (30), 144 (18), 143 (61), 130 (100), 115 (22), 77 (10); HRMS-EI: $m / z$ [M] calcd for $\mathrm{C}_{14} \mathrm{H}_{18} \mathrm{O}_{2} \mathrm{~N}_{2}$ : 246.1368; found: 246.1370 .

3-(3-Methyl-1-nitromethylbutyl)-1H-indole (2m): ${ }^{1} \mathrm{H}-\mathrm{NMR}\left(400 \mathrm{MHz}, \mathrm{CDCl}_{3}\right.$ ): $\delta 8.07$ (brs, $\left.1 \mathrm{H}\right), 7.62$ $(\mathrm{d}, J=7.8 \mathrm{~Hz}, 1 \mathrm{H}), 7.33(\mathrm{~d}, J=8.1 \mathrm{~Hz}, 1 \mathrm{H}), 7.20(\mathrm{~m}, 1 \mathrm{H}), 7.13(\mathrm{~m}, 1 \mathrm{H}), 6.99(\mathrm{~d}, J=2.2 \mathrm{~Hz}, 1 \mathrm{H}), 4.59$ $(\mathrm{m}, 2 \mathrm{H}), 3.87(\mathrm{~m}, 1 \mathrm{H}), 1.89(\mathrm{~m}, 1 \mathrm{H}), 1.51(\mathrm{~m}, 2 \mathrm{H}), 0.88(\mathrm{dd}, J=6.0$ and $5.7 \mathrm{~Hz}, 6 \mathrm{H}) ;{ }^{13} \mathrm{C}-\mathrm{NMR}(100$ $\left.\mathrm{MHz}, \mathrm{CDCl}_{3}\right): \delta 136.5(\mathrm{C}), 126.1(\mathrm{C}), 122.3(\mathrm{CH}), 119.7(\mathrm{CH}), 118.7(\mathrm{CH}), 113.9(\mathrm{C}), 111.5(\mathrm{CH})$, $80.9\left(\mathrm{CH}_{2}\right), 41.4\left(\mathrm{CH}_{2}\right), 34.4(\mathrm{CH}), 25.4(\mathrm{CH}), 23.3(\mathrm{CH}), 21.5\left(\mathrm{CH}_{3}\right)$; MS (EI) $\mathrm{m} / \mathrm{z}$ (relative intensity): 246 (24) [M] $]^{+}, 157$ (26), 144 (36), 143 (71), 130 (100), 115 (24), 84 (19), 57 (31), 55 (25); HRMS-EI: $\mathrm{m} / \mathrm{z}[\mathrm{M}]^{+}$calcd for $\mathrm{C}_{14} \mathrm{H}_{18} \mathrm{O}_{2} \mathrm{~N}_{2}: 246.1368$; found: 246.1365 .

3-(2-Nitro-1-phenylethyl)-1H-indol-4-ol (4h): ${ }^{1} \mathrm{H}-\mathrm{NMR}\left(400 \mathrm{MHz}, \mathrm{CDCl}_{3}\right): \delta 7.94$ (brs, 1H), 7.31$7.24(\mathrm{~m}, 4 \mathrm{H}), 7.18(\mathrm{~d}, J=9.4 \mathrm{~Hz}, 1 \mathrm{H}), 6.93(\mathrm{t}, J=7.8 \mathrm{~Hz}, 1 \mathrm{H}), 6.85(\mathrm{~d}, J=8.1 \mathrm{~Hz}, 1 \mathrm{H}), 6.64(\mathrm{~s}, 1 \mathrm{H})$, $6.32(\mathrm{~d}, J=7.5 \mathrm{~Hz}, 1 \mathrm{H}), 5.43(\mathrm{t}, J=8.1 \mathrm{~Hz}, 1 \mathrm{H}), 5.23(\mathrm{dd}, J=12.7$ and $6.6 \mathrm{~Hz}, 1 \mathrm{H}), 5.11(\mathrm{brs}, 1 \mathrm{H})$, $4.87(\mathrm{t}, J=11.8 \mathrm{~Hz}, 1 \mathrm{H}) ;{ }^{13} \mathrm{C}-\mathrm{NMR}\left(100 \mathrm{MHz}, \mathrm{CDCl}_{3}\right): \delta 149.7(\mathrm{C}), 139.7(\mathrm{C}), 138.9(\mathrm{C}), 128.8(\mathrm{CH})$, $127.8(\mathrm{CH}), 127.4(\mathrm{CH}), 123.4(\mathrm{CH}), 121.8(\mathrm{C}), 115.5(\mathrm{CH}), 114.7(\mathrm{C}), 104.8(\mathrm{CH}), 104.5(\mathrm{CH}), 79.8$ $\left(\mathrm{CH}_{2}\right), 42.1(\mathrm{CH})$; MS (EI) $\mathrm{m} / \mathrm{z}$ (relative intensity): $282(54)[\mathrm{M}]^{+}, 236$ (47), 235 (100), 234 (32), 222 (70), 220 (45), 117 (14), 103 (17), 77 (12); HRMS-EI: m/z [M] calcd for $\mathrm{C}_{16} \mathrm{H}_{14} \mathrm{O}_{3} \mathrm{~N}_{2}: 282.1004$; found: 282.1000 .

3-(2-Nitro-1-phenylethyl)-1H-indol-4-yl acetate (4i): ${ }^{1} \mathrm{H}-\mathrm{NMR}\left(400 \mathrm{MHz}, \mathrm{CDCl}_{3}\right): \delta 8.16$ (brs, $\left.1 \mathrm{H}\right)$, 7.27-7.06 (m, 7H), $6.79(\mathrm{~d}, J=6.8 \mathrm{~Hz}, 1 \mathrm{H}), 6.65(\mathrm{~s}, 1 \mathrm{H}), 5.19(\mathrm{~m}, 1 \mathrm{H}), 5.01(\mathrm{dd}, J=12.8$ and $6.5 \mathrm{~Hz}$, $1 \mathrm{H}), 4.85(\mathrm{dd}, J=11.8$ and $9.9 \mathrm{~Hz}, 1 \mathrm{H}), 2.21(\mathrm{~s}, 3 \mathrm{H}) ;{ }^{13} \mathrm{C}-\mathrm{NMR}\left(100 \mathrm{MHz}, \mathrm{CDCl}_{3}\right): \delta 170.3(\mathrm{C}), 143.8$ (C), $139.0(\mathrm{C}), 138.9(\mathrm{C}), 129.0(\mathrm{CH}), 127.8(\mathrm{CH}), 127.7(\mathrm{CH}), 124.0(\mathrm{CH}), 122.8(\mathrm{CH}), 118.5(\mathrm{CH})$, $113.2(\mathrm{C}), 112.6(\mathrm{CH}), 109.7(\mathrm{CH}), 79.9\left(\mathrm{CH}_{2}\right), 42.0(\mathrm{CH}), 21.3\left(\mathrm{CH}_{3}\right) ; \mathrm{MS}(\mathrm{EI}) \mathrm{m} / \mathrm{z}$ (relative intensity): 324 (16) [M] $]^{+}, 282$ (68), 236 (55), 235 (100), 222 (49); HRMS-EI: m/z [M] calcd for $\mathrm{C}_{18} \mathrm{H}_{16} \mathrm{~N}_{2} \mathrm{O}_{4}$ : 324.1110; found: 324.1111 .

3-(2-Nitro-1-phenylethyl)-1H-pyrrolo[2,3-b]pyridine (4j): ${ }^{1} \mathrm{H}-\mathrm{NMR}$ (400 $\left.\mathrm{MHz}, \mathrm{CDCl}_{3}\right): \delta 8.31$ $(\mathrm{d}, J=3.5 \mathrm{~Hz}, 1 \mathrm{H}), 7.87(\mathrm{dd}, J=7.7$ and $1.1 \mathrm{~Hz}, 1 \mathrm{H}), 7.33-7.30(\mathrm{~m}, 5 \mathrm{H}), 7.20(\mathrm{~d}, J=3.5 \mathrm{~Hz}, 1 \mathrm{H})$, $7.07(\mathrm{dd}, J=7.7$ and $4.7 \mathrm{~Hz}, 1 \mathrm{H}), 6.71(\mathrm{dd}, J=9.2$ and $6.1 \mathrm{~Hz}, 1 \mathrm{H}), 6.47(\mathrm{~d}, J=3.6 \mathrm{~Hz}, 1 \mathrm{H}), 5.37$ (dd, $J=13.4$ and $9.2 \mathrm{~Hz}, 1 \mathrm{H}), 5.16(\mathrm{dd}, J=13.4$ and $6.1 \mathrm{~Hz}, 1 \mathrm{H}) .{ }^{13} \mathrm{C}-\mathrm{NMR}\left(100 \mathrm{MHz}, \mathrm{CDCl}_{3}\right): \delta 147.6$ (C), $143.2(\mathrm{CH}), 135.9(\mathrm{C}), 129.3(\mathrm{CH}), 129.1(\mathrm{CH}), 129.0(\mathrm{CH}), 128.8(\mathrm{CH}), 127.0(\mathrm{CH}), 126.0(\mathrm{CH})$, $121.0(\mathrm{C}), 116.6(\mathrm{CH}), 101.4(\mathrm{C}), 56.7\left(\mathrm{CH}_{2}\right)$; MS (EI) m/z (relative intensity): $267(5)[\mathrm{M}]^{+}, 221(21)$, 
149 (11), 118 (100), 102 (18), 91 (70), 84 (25), 77 (45), 63 (21), 51 (28); HRMS-EI: m/z [M] calcd for $\mathrm{C}_{15} \mathrm{H}_{13} \mathrm{O}_{2} \mathrm{~N}_{3}$ : 267.1008; found: 267.1005 .

\section{Acknowledgements}

Financial support of this work by the National Science Council of the Republic of China is gratefully acknowledged.

\section{References}

1. Lim, K.H.; Hiraku, O.; Komiyama, K.; Koyano, T.; Hayashi, M.; Kam, T.S. Biologically active indole alkaloids from Kopsia arborea. J. Nat. Prod. 2007, 70, 1302-1307.

2. Sundberg, R.J. Indoles; Academic Press: London, UK, 1996.

3. Faulkner, D.J. Marine natural products. Nat. Prod. Rep. 2001, 18, 1-49.

4. Fukuyama, T.; Chen, X. Stereocontrolled synthesis of (-)-Hapalindole G. J. Am. Chem. Soc. 1994, 116, 3125-3126.

5. Moore, R.E.; Cheuk, C.; Yang, X.Q.G.; Patterson, G.M.L.; Bonjouklian, R.; Smitka, T.A.; Mynderse, J.S.; Foster, R.S.; Jones, N.D. Hapalindoles, antibacterial and antimycotic alkaloids from the cyanophyte Hapalosiphon fontinalis. J. Org. Chem. 1987, 52, 1036-1043.

6. Moore, R.E.; Cheuk, C.; Patterson, G.M.L. Hapalindoles: New alkaloids from the blue-green alga Hapalosiphon fontinalis. J. Am. Chem. Soc. 1984, 106, 6456-6457.

7. Wang, S.Y.; Ji, S.J.; Loh, T.P. The Michael addition of indole to $\alpha, \beta$-unsaturated ketones catalyzed by iodine at room temperature. Synlett 2003, 2377-2379.

8. Olah, G.A.; Krishnamurthy, R. Prakash, G.K.S. In Comprehensive Organic Synthesis, 1st ed.; Trost, B.M., Fleming, I., Eds.; Pergamon: Oxford, UK. 1991; Vol. 3, pp. 293-339.

9. Harrington, P.E.; Kerr, M.A. Reaction of indoles with electron deficient olefins catalyzed by $\mathrm{Yb}(\mathrm{OTf})_{3} \cdot 3 \mathrm{H}_{2} \mathrm{O}$. Synlett 1996, 1047-1048.

10. Kumar, V.P.; Sridhar, R.; Srinivas, B.; Narender, M.; Rao, K.R. Friedel-Crafts alkylation of indoles with nitroolefins in the presence of beta-cyclodextrin in water under neutral conditions. Can. J. Chem. 2008, 86, 907-911.

11. Yadav, J.S.; Abraham, S.; Reddy, B.V.S.; Sabitha, G. $\mathrm{InCl}_{3}$-catalysed conjugate addition of indoles with electron-deficient olefins. Synthesis 2001, 2165-2169.

12. Bandini, M.; Melchiorre, P.; Melloni, A.; Umani-Ronchi, A. A practical indium tribromide catalysed addition of indoles to nitroalkenes in aqueous media. Synthesis 2002, 1110-1114.

13. Zhan, Z.P.; Yanga, R.F.; Langa, K. Samarium triiodide-catalyzed conjugate addition of indoles with electron-deficient olefins. Tetrahedron Lett. 2005, 46, 3859-3862.

14. Bartoli, G.; Bosco, M.; Giuli, S.; Giuliani, A.; Lucarelli, L.; Marcantoni, E.; Sambri, L.; Torregiani, E. Efficient preparation of 2-indolyl-1-nitroalkane derivatives employing nitroalkenes as versatile Michael acceptors: New practical linear approach to alkyl $9 H-\beta$-carboline-4carboxylate. J. Org. Chem. 2005, 70, 1941-1944.

15. Lin, C.; Hsu, J.; Sastry, M.N.V.; Fang, H.; Tu, Z.; Liu, J.T.; Yao, C.F. I2-catalyzed Michael addition of indole and pyrrole to nitroolefins. Tetrahedron 2005, 61, 11751-11757. 
16. Firouzabadi, H.; Iranpoor, N.; Nowrouzi, F. The facile and efficient Michael addition of indoles and pyrrole to $\alpha, \beta$-unsaturated electron-deficient compounds catalyzed by aluminium dodecyl sulfate trihydrate $\left[\mathrm{Al}(\mathrm{DS})_{3}\right] \cdot 3 \mathrm{H}_{2} \mathrm{O}$ in water. Chem. Commun. 2005, 789-791.

17. Azizi, N.; Arynasab, F.; Saidi, M.R. Efficient Friedel-Crafts alkylation of indoles and pyrrole with enones and nitroalkene in water. Org. Biomol. Chem. 2006, 4275-4277.

18. Ballini, R.; Clemente, R.R.; Palmieri, A.; Petrini, M.; Conjugate addition of indoles to nitroalkenes promoted by basic alumina in solventless conditions. Adv. Synth. Catal. 2006, 348, 191-196.

19. An, L.T.; Zou, J.P.; Zhang, L.L.; Zhang, Y. Sulfamic acid-catalyzed Michael addition of indoles and pyrrole to electron-deficient nitroolefins under solvent-free condition. Tetrahedron Lett. 2007, 48, 4297-4300.

20. Wu, P.; Wan, Y.; Cai, J. Carbohydrate-Based Tolylsulfonyl Hydrazines: Effective catalysts for Michael addition of indoles to electron-deficient olefins in water. Synlett 2008, 1193-1198.

21. Chakrabarty, M.; Basak, R.; Ghosh, N.; Harigaya, Y. Michael reaction of indoles with 3-(2'nitrovinyl)indole under solvent-free conditions and in solution. An efficient synthesis of 2,2bis(indolyl)nitroethanes and studies on their reduction. Tetrahedron 2004, 60, 1941-1949.

22. Kusurkar, R.S.; Alkobati, N.A.H.; Gokule, A.S.; Chaudhari, P.M.; Waghchaure, P.B. Thermal and microwave-assisted conjugate additions of indole on electron-deficient nitro-olefins. Synth. Commun. 2006, 36, 1075-1081.

23. Itoh, J.; Fuchibe, K.; Akiyama, T. Chiral phosphoric acid catalyzed enantioselective FriedelCrafts alkylation of indoles with nitroalkenes: Cooperative effect of $3 \AA$ molecular sieves. Angew. Chem. Int. Ed. 2008, 47, 4016-4018.

24. Ganesh, M.; Seidel, D. Catalytic enantioselective additions of indoles to nitroalkenes. J. Am. Chem. Soc. 2008, 130, 16464-16465.

25. Zhang, P.; Liu, R.; Cook, J.M. Regiospecific bromination of 3-methylindoles with $\mathrm{N}$ bromosuccinimide. Tetrahedron Lett. 1995, 36, 3103-3106.

26. Fukase, K.; Hasuoka, A.; Kinoshita, I.; Aoki, Y.; Kasumoto, S. Regiospecific bromination of 3methylindoles with $\mathrm{N}$-bromosuccinimide. Tetrahedron 1995, 51, 4923-4932.

27. Karimi, B.; Hazarkhani, H.; Maleki, J. N-Bromosuccinimide (NBS) catalyzed highly chemoselective acetalization of carbonyl compounds using silylated diols and pentaerythritol under neutral aprotic conditions. Synthesis 2005, 279-285.

28. Iranpoor, N.; Firouzabadi, H.; Shaterian, H.R. Catalytic and chemoselective deprotection of S,Sand S,O-acetals and ketals in the presence of their O,O-analogs with electrophilic halogens under neutral conditions. Tetrahedron Lett. 2003, 44, 4769-4773.

29. Narender, M.; Reddy, M.S.; Rao, K.R.A mild and efficient oxidative deprotection of THP ethers with NBS in the presence of $\beta$-cyclodextrin in water. Synthesis 2004, 1741-1743.

30. Koshima, H.; Matsusaka, W. N-Bromosuccinimide catalyzed condensations of indoles with carbonyl compounds under solvent-free conditions. J. Heterocycl. Chem. 2002, 39, 1089-1092.

31. Surendra, K.; Krishnaveni, N.S.; Kumar, V.P.; Sridhar, R.; Rao, K.R. Selective and efficient oxidation of sulfides to sulfoxides with $N$-bromosuccinimide in the presence of $\beta$-cyclodextrin in water. Tetrahedron Lett. 2005, 46, 4581-4583. 
32. Ohno, M.; Spande, T.F.; Witkop, B. Cyclization of tryptophan and tryptamine derivatives to pyrrolo[2,3-b]indoles. J. Am. Chem. Soc. 1968, 90, 6521-6522.

33. Sakurai, O.; Takashahi, M.; Ogiku, T.; Hayashi, M.; Horikawa, H.; Iwasaki, T. A new synthesis of $1 \beta$-methylcarbapenems using NBS-promoted cyclization as a key step. Tetrahedron Lett. 1994, 35, 6317-6320.

34. Kuo, C.W.; More, S.V.; Yao, C.F. NBS as an efficient catalyst for the synthesis of 1,5benzodiazepine derivatives under mild conditions. Tetrahedron Lett. 2006, 47, 8523-8528.

35. Tu, Z.; Raju, B.R.; Liou, T.R.; Kavala, V.; Kuo, C.W.; Jang, Y.; Shih, Y.H.; Wang, C.C.; Yao, C.F. An efficient method for the synthesis of $\alpha$-arylated nitroalkanes and $\alpha$-arylated hydroximoyl chlorides mediated by $\mathrm{AlCl}_{3}$. Tetrahedron 2009, 65, 2436-2442.

36. Habib, P.M.; Kavala, V.; Kuo, C.W.; Yao, C.F. Catalyst-free aqueous-mediated conjugative addition of indoles to $\beta$-nitrostyrenes. Tetrahedron Lett. 2008, 49, 7005-7007.

37. Tu, Z.; Jang, Y.; Lin, C.; Liu, J.T.; Hsu, J.; Sastry, M.N.V.; Yao, C.F. The study of reaction mechanism for the transformation of nitronate into nitrile by phosphorus trichloride. Tetrahedron 2005, 61, 10541-10551.

38. Yan, M.C.; Jang, Y.J.; Wu, J.; Lin, Y.F.; Yao, C.F. Radical reactions in esters with alkoxy functionality chemistry an unusual alcohol moiety hydrogen abstraction. Tetrahedron Lett. 2004, 45, 3685-3688.

39. Yao, C.F.; Jang, Y.J.; Yan, M.C. An easy and efficient synthesis of 3-nitrochromans. Tetrahedron Lett. 2003, 44, 3813-3816.

40. Yan, M.C.; Tu, Z.; Lin, C.; Yao, C.F. An easy and efficient method for the synthesis of hydroximoyl chloride from nitro olefin and silyl enol ether. Tetrahedron Lett. 2002, 43, 7991- 7994.

41. Liu, J.T.; Yao, C.F. One-pot synthesis of trans- $\beta$-alkylstyrenes. Tetrahedron Lett. 2001, 42, $6147-6150$.

42. Yan, M.C.; Jang, Y.J.; Yao, C.F. An easy and efficient method for the synthesis of 2,2-dialkyl-3nitrochromene. Tetrahedron Lett. 2001, 42, 2717-2721.

43. Liu, J.Y.; Liu, J.T.; Yao, C.F. Novel synthesis of alkenes via triethylaluminum-induced free radical reactions of alkyl iodides and $\beta$-nitrostyrenes. Tetrahedron Lett. 2001, 42, 3613-3615.

44. Yamamoto, H. Lewis Acid Reagents; Oxford University Press: New York, NY, USA, 1999.

45. Itoh, K.; Kishimoto, S. The reaction of $\beta$-nitrostyrenes with 2-methoxyfuran: a novel formation of isoxazoline $N$-oxide together with Michael adducts. New J. Chem. 2000, 24, 347-349.

46. Mahboobi, S.; Popp, A.; Burgemeister, T.; Schollmeyer, D. Diastereoselective synthesis of (-)-1methyl-(3S,4R)-3,4-bis((2S)- $N$-(tert-butyloxycarbonyl)pyrrolidin-2-yl)-2-pyrrolidinone by an asymmetric Michael reaction. Tetrahedron Asymmetry 1998, 9, 2369-2376.

Sample Availability: Samples of the compounds are available from the authors.

(C) 2009 by the authors; licensee Molecular Diversity Preservation International, Basel, Switzerland. This article is an open-access article distributed under the terms and conditions of the Creative Commons Attribution license (http://creativecommons.org/licenses/by/3.0/). 